Proc. Estonian Acad. Sci. Geol., 2006, 55, 3, 241-251

\title{
New correlations of Telychian (Silurian) bentonites in Estonia
}

\author{
Toivo Kallaste and Tarmo Kiipli \\ Institute of Geology at Tallinn University of Technology, Estonia pst. 7, 10143 Tallinn, Estonia; \\ tarmo.kiipli@1x.egk.ee \\ Received 18 May 2006, in revised form 27 June 2006

\begin{abstract}
Seventy-seven Telychian bentonite samples from six drill-core sections were correlated on the basis of their sanidine composition. In total, bentonites from 43 volcanic eruptions, of which six are new discoveries, were established in the Telychian of Estonia. Names and identification (ID) codes were assigned to the bentonites. The different distribution patterns of volcanic ash thicknesses indicate different source volcanoes. Lack of several bentonites near the transition between the Rumba and Velise formations and at the Llandovery-Wenlock boundary indicates sedimentary hiatuses in the eastern part of the studied area.
\end{abstract}

Key words: bentonite, K-bentonite, Telychian, sanidine, correlation.

\section{INTRODUCTION}

The use of bentonites in the correlation of geological sections offers a unique possibility for recognition of exactly the same time levels in several outcrop and drill-core sections (e.g. Einasto et al. 1972). Limestones (Rumba Formation) and marlstones (Velise Formation) of the Adavere Stage contain a large number of thin altered volcanic ash beds - bentonites (Jürgenson 1964). These regional stratigraphic units belong to the Telychian Stage of the international stratigraphic scheme (Bergström et al. 1998; Nestor \& Nestor 2002; Kiipli et al. 2006). The sanidine composition has been studied in twelve drill-cores with an aim to identify the ash beds in the Telychian of Estonia. The results show that the volcanogenic interbeds originate from at least 37 different eruptions (Kiipli et al. 2001; Kiipli \& Kallaste 2002), although the greatest number of bentonite interbeds found in one section is only 22 .

The aims of bentonite study are precise correlation of sections, mapping of the distribution of bentonites, and restoration of wind directions at the eruption time and locations of source volcanoes. Herein, we are going to report the results 
obtained through the study of bentonites in six new sections using the same method as in Kiipli \& Kallaste (2002). To bring some clarity to this rather difficult and confused subject, identification (ID) codes were assigned to all the identified bentonites. Names were given to more widespread bentonites.

\section{MATERIAL AND METHODS}

Seventy-seven bentonite samples from six drill-cores (see Fig. 1) were collected from $0.2-20 \mathrm{~cm}$ thick interbeds, which differed from their host marlstones and limestones in their soft clayish consistency and/or in colour. The abundance of biotite flakes was a good criterion for recognizing volcanogenic bentonites in situ. For correlation purposes, the data on bentonites studied earlier in the

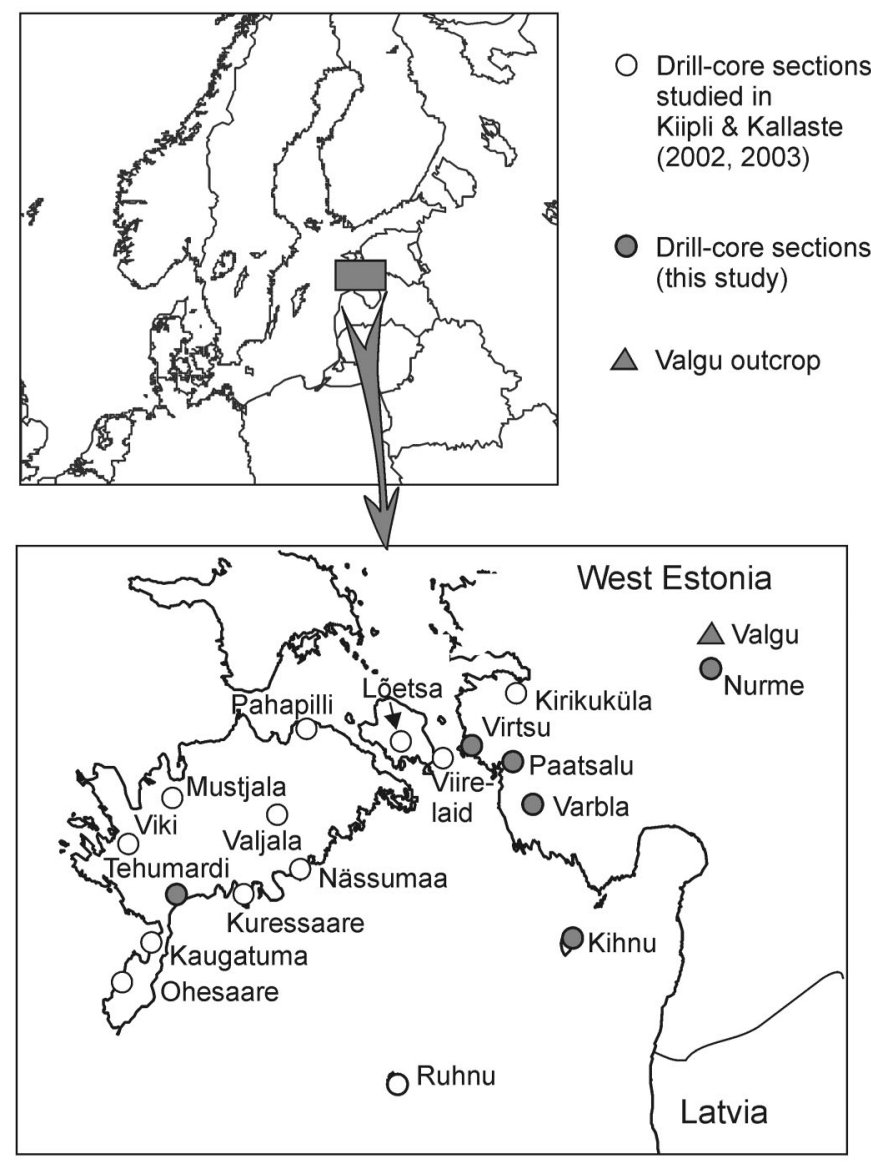

Fig. 1. Location of the studied sections. 
Ohesaare, Viki, and Ruhnu sections were used (Kiipli \& Kallaste 2002, 2003). The lithology and distribution of microfossils of many studied sections are discussed in Einasto et al. (1972), Jeppsson \& Männik (1993), Nestor (1994), and Hints et al. (2006).

All bulk samples were scanned by X-ray diffractometry (XRD) from 5 to 45 degrees using Co $\mathrm{K} \alpha$ radiation. The occurrence of illite-smectite and/or kaolinite reflections was considered as an indication of volcanogenic material. Some volcanogenic interbeds had a high content of authigenic potassium feldspar. A low content or absence of quartz was typical of bulk volcanogenic bentonite material.

The Na content of K-Na sanidine was studied by XRD (Kiipli \& Kallaste 2002). From the separated $0.04-0.1 \mathrm{~mm}$ fraction the range from 23.5 to $26.0^{\circ} 2 \theta$ was scanned using $\mathrm{Co} \mathrm{K} \alpha$ radiation with the step size of $0.01^{\circ} 2 \theta$; the measuring time was $15 \mathrm{~s}$ per point. The content of $\mathrm{NaAlSi}_{3} \mathrm{O}_{8}$ in $\mathrm{K}-\mathrm{Na}$ sanidine (in mol \%) was calculated according to Orville (1967), who established that the position of the $20 \overline{1}$ reflection almost linearly depends on the composition of sanidine solid solution. The precision of the analysis of the $\mathrm{K}-\mathrm{Na}$ sanidine composition was $\pm 1 \%$ in favourable cases (low intensity of authigenic feldspar reflection, no kaolinite, high intensity of the reflection of interest) and $\pm 2 \%$ in less favourable cases. Separate beds were correlated on the basis of the magmatic K-Na sanidine composition (Table 1). As several bentonites may have the same sanidine composition, graphic correlation between sections was applied to improve the probability of correlations.

\section{RESULTS}

The $\mathrm{NaAlSi}_{3} \mathrm{O}_{8}$ content of sanidine varied from $21 \mathrm{~mol} \%$ in the Osmundsberg Bentonite to $45-48 \mathrm{~mol} \%$ in the Valgu, Ruhnu, and Viki bentonites. The width of the sanidine reflection varied from sharp $\left(0.05-0.15^{\circ} 2 \theta\right.$; indicating homogeneous sanidine composition) to very wide (exceeding $0.35^{\circ} 2 \theta$ ). Such wide reflections were difficult to characterize in numerical values and were described as wide or very wide (Table 1). A wide sanidine reflection clearly discriminates a particular bentonite from those with sharp reflections, but is useless for discrimination between other bentonites with wide sanidine reflections. Wide reflections probably indicate heterogeneous (maybe zoned) sanidine crystals.

By combining sanidine properties and graphic correlation most of the studied bentonites can be correlated with volcanogenic interbeds established earlier in other drill-cores (Table 2). Many volcanic eruptions have been detected in more than five sections, thus their stratigraphic position among other bentonites is well proven. Compared with the earlier study (Kiipli \& Kallaste 2002), six new volcanic eruptions have been established: ID 504, 720, 750, 773, 793, and 794, five of those only in one section. ID 504 was additionally found in the earlier studied Kaugatuma section at a depth of $262.2 \mathrm{~m}$ and possibly in the new Kihnu section in the lower part of the $10 \mathrm{~cm}$ thick bentonite at a depth of $211.95 \mathrm{~m}$. The total number of Telychian volcanic eruptions recorded in Estonia is 43. 
Table 1. Sanidine properties of Telychian bentonites

\begin{tabular}{|c|c|c|c|c|c|c|}
\hline \multicolumn{3}{|c|}{ Identification numbers and names } & \multirow{2}{*}{$\begin{array}{l}\text { Num- } \\
\text { ber of } \\
\text { sec- } \\
\text { tions }\end{array}$} & \multirow[t]{2}{*}{$\begin{array}{l}\text { Stage and } \\
\text { formation }\end{array}$} & \multicolumn{2}{|c|}{$\begin{array}{l}\text { Pyroclastic K-Na sanidine, } \\
\text { main component parameters }\end{array}$} \\
\hline $\begin{array}{c}\text { Viki } \\
\text { depth } \\
\text { ID }\end{array}$ & \begin{tabular}{|c} 
Interpo- \\
lated depth \\
in the Viki \\
core, $\mathrm{m}$
\end{tabular} & $\begin{array}{l}\text { Bentonite } \\
\text { name }\end{array}$ & & & $\begin{array}{c}\text { Width of the } \\
\text { reflection } \\
\text { (degrees) } \\
\text { and other notes }\end{array}$ & $\begin{array}{c}\text { Content of } \\
\mathrm{NaAlSi}_{3} \mathrm{O}_{8} \text { in } \\
\text { sanidine, } \\
\text { mol \% }\end{array}$ \\
\hline 127 & 112.70 & Ireviken & 6 & Jaani Stage & \multicolumn{2}{|c|}{ Much of biotite and quartz, little sanidin } \\
\hline 150 & 115.00 & Lusklint & 7 & Mustjala & $0.19-0.34$ & $35.2-35.8$ \\
\hline 210 & 121.00 & Ohesaare & 6 & Formation & $0.25-0.35$ & $38-40$ \\
\hline 311 & 131.10 & Aizpute & 6 & & $0.08-0.12$ & $36.2-37.8$ \\
\hline 457 & 145.75 & Kirikuküla & 10 & & Very wide reflect & \\
\hline 475 & 147.50 & Viki & 12 & & $0.12-0.20$ & $45.2-46.3$ \\
\hline 480 & 148.00 & Kaugatuma & 6 & & $0.18-0.27$ & $42.0-42.8$ \\
\hline 488 & 148.80 & Kuressaare & 8 & & Very wide reflect & \\
\hline 494 & 149.40 & Ruhnu & 14 & & $0.05-0.09$ & $45.7-46.4$ \\
\hline 504 & 150.40 & & 2 & & $0.08-0.20$ & $45.6-46.6$ \\
\hline 518 & 151.80 & Viirelaid & 10 & & Very wide reflect & \\
\hline 520 & 152.00 & Lõetsa & 10 & & Very wide reflect & \\
\hline 521 & 152.10 & & $8 ?$ & & Very wide reflect & \\
\hline 564 & 156.40 & & 3 & & $0.12-0.17$ & $45.0-45.8$ \\
\hline 568 & 156.80 & & $10 ?$ & & Very wide reflect & \\
\hline 569 & 156.90 & & 1 & & 0.07 & 29.0 \\
\hline 658 & 165.80 & & 2 & & 0.09 & 45.5 \\
\hline 682 & 168.20 & & 2 & & Very wide reflect & \\
\hline 693 & 169.30 & & 2 & & 0.05 & 22.6 \\
\hline 696 & 169.60 & Nässumaa & 13 & Adavere Stage & $0.04-0.06$ & $22.9-23.3$ \\
\hline 719 & 171.95 & Virtsu & 12 & Velise & Much of biotite a & quartz, little sanidine \\
\hline 720 & 172.00 & & 1 & Formation & $0.085-0.122$ & $26.5-28.0$ \\
\hline 722 & 172.20 & & 2 & & $26.5+$ wide reflec & \\
\hline 731 & 173.10 & Nurme & 13 & & $0.10-0.16$ & $38.7-40.3$ \\
\hline 744 & 174.40 & Tehumardi & 11 & & $0.07-0.10$ & $25.8-26.7$ \\
\hline 750 & 175.00 & & 1 & & Wide reflection & \\
\hline 755 & 175.55 & Paatsalu & 8 & & $0.25-0.30$ & $25.5-26.2$ \\
\hline 772 & 177.20 & Pahapilli & 8 & & $0.30-0.34$ & $20.5-24.1$ \\
\hline 773 & 177.30 & & 1 & & Feldspathic & \\
\hline 774 & 177.40 & & 1 & & $0.09-0.12$ & $46.2-48.2$ \\
\hline 776 & 177.60 & & 5 & & $0.07-0.08$ & $28.1-28.8$ \\
\hline 777 & 177.70 & & 2 & & $0.25-0.30$ & $22.3-26.2$ \\
\hline 788 & 178.80 & & 2 & & $0.17-0.19$ & 40.1-40.6 \\
\hline 793 & 179.30 & & 1 & & Biotite flakes on 1 & ding plane \\
\hline 794 & 179.40 & & 1 & & 0.12 & 43.7 \\
\hline 795 & 179.50 & Mustjala & 6 & & $0.05-0.11$ & $24.5-25.3$ \\
\hline 800 & 180.00 & & 2 & & Feldspathic & \\
\hline 805 & 180.50 & & 2 & Adavere Stage & Feldspathic & \\
\hline 818 & 181.80 & & 3 & Rumba-Velise & Very wide reflect & \\
\hline 823 & 182.30 & Valgu & 5 & transition & $0.12-0.17$ & $45.2-47.6$ \\
\hline 841 & 184.15 & & 2 & & $0.19-0.22$ & $35.5-35.8$ \\
\hline 843 & 184.35 & & 3 & Adavere Stage & Very wide reflect & \\
\hline 851 & 185.10 & Osmundsberg & 15 & Rumba & $0.05-0.09$ & $20.7-21.5$ \\
\hline 880 & 188.00 & & 4 & Formation & Very wide reflect & \\
\hline
\end{tabular}


Table 2. Correlated Telychian bentonites in the studied core sections (depth in metres). Small font indicates that sanidine was not studied - graphic correlation was used. Provisional correlation is embraced by a frame

\begin{tabular}{|c|c|c|c|c|c|c|c|c|c|}
\hline $\begin{array}{l}\text { Viki depth } \\
\text { ID }\end{array}$ & Viki & $\begin{array}{c}\text { Kures- } \\
\text { saare }\end{array}$ & $\begin{array}{l}\text { Ohe- } \\
\text { saare }\end{array}$ & Ruhnu & Kihnu & Varbla & $\begin{array}{l}\text { Paat- } \\
\text { salu }\end{array}$ & Virtsu & Nurme \\
\hline 127 & & 158.30 & 340.76 & & & & & & \\
\hline 150 & 115.00 & 160.00 & 342.08 & & & & & & \\
\hline 210 & 121.00 & & 345.83 & & & 134.90 & & & \\
\hline 311 & 131.10 & & 351.72 & 459.00 & & 137.20 & & & \\
\hline 457 & 145.75 & & 359.31 & 467.60 & 211.20 & 139.40 & & 68.55 & \\
\hline 475 & 147.50 & & 361.30 & 470.80 & 211.70 & 139.85 & 72.50 & 69.20 & \\
\hline 480 & 148.00 & & 361.70 & 471.80 & & & & & \\
\hline 488 & 148.80 & 184.80 & 362.23 & 473.10 & & & & & \\
\hline 494 & 149.40 & 185.40 & 362.46 & 473.70 & 211.85 & 140.28 & & 69.50 & \\
\hline 504 & & & & & 211.95 & & & & \\
\hline 518 & 151.80 & 187.40 & 364.76 & 478.90 & 212.20 & & 73.70 & & \\
\hline 520 & & 188.50 & & & & & 74.00 & 71.30 & \\
\hline 521 & 152.10 & 189.50 & 365.08 & 478.90 & 214.50 & 141.50 & & & \\
\hline 564 & & & 367.39 & & & & & & \\
\hline 568 & 156.80 & 193.75 & 367.60 & & 215.70 & 143.25 & & & \\
\hline 569 & & & & & 215.72 & & & & \\
\hline 658 & & & 369.12 & & & & & & \\
\hline 682 & & 205.20 & & & & & & & \\
\hline 693 & & & 369.72 & & & & & & \\
\hline 696 & 169.60 & & 369.75 & 488.24 & 220.70 & 146.90 & & 79.25 & \\
\hline 719 & 171.95 & 205.40 & & 488.30 & 221.70 & 148.00 & 80.80 & 80.20 & \\
\hline 720 & & & & 488.30 & & & & & \\
\hline 722 & & & & 488.40 & & & & & \\
\hline 731 & 173.10 & & 369.98 & 489.05 & 222.30 & 148.20 & 81.05 & 80.68 & 17.90 \\
\hline 744 & 174.40 & & & 489.05 & 222.70 & 148.60 & 81.09 & & 20.10 \\
\hline 750 & & 209.20 & & & & & & & \\
\hline 755 & 175.55 & & 370.09 & & 223.10 & & 81.50 & & 21.10 \\
\hline 772 & & 210.20 & 370.44 & & & & 82.00 & 81.40 & 23.45 \\
\hline 773 & & & & & & & 82.10 & & \\
\hline 774 & & 210.30 & & & & & & & \\
\hline 776 & & & 370.63 & & & & 82.40 & & \\
\hline 777 & & & & & & & 82.40 & & \\
\hline 788 & 178.80 & & & & & & & & \\
\hline 793 & & & & & & & 83.75 & & \\
\hline 794 & & 212.70 & & & & & & & \\
\hline 795 & & 212.80 & & & & 150.40 & 83.90 & & \\
\hline 800 & & & & & & 150.75 & & & \\
\hline 805 & & & & & & & & & 24.50 \\
\hline 818 & 181.80 & 214.00 & 370.77 & & & & & & 24.60 \\
\hline 823 & 182.30 & & 370.77 & & & & & & \\
\hline 841 & & & 370.99 & & & & & & \\
\hline 843 & 184.35 & & & & & & & & \\
\hline 851 & 185.10 & 215.70 & & & 228.40 & 155.60 & 88.20 & & \\
\hline 880 & & 223.80 & & & & 158.30 & & & \\
\hline
\end{tabular}




\section{BENTONITE IDENTIFICATION NUMBERS AND NAMES}

The former bentonite ID numbers (Kiipli et al. 2001) started from 0 (Osmundsberg Bentonite) and were assigned in stratigraphic order up- and downward from it. However, difficulties arose when new bentonites were found, because no vacant numbers were available between the earlier known and numbered bentonites. Therefore, new bentonite finds were left without an ID number in Kiipli \& Kallaste (2002).

In the present study, new stratigraphic ID numbers were assigned to all established bentonites. The ID numbers were derived from the projection of the bentonite stratigraphic position to the Viki drill-core depth scale. The number marks the depth in decimetres in the Viki section. For the sake of shortness, centimetres were discarded from the end of the depth number. Besides, 1000 decimetres were subtracted from the depth, as all bentonites occur between 1000 and 2000 decimetre depth. This combination resulted in a list of three-digit ID codes for bentonites (Tables 1-3). Any new bentonite find can be easily accommodated into this list. The Viki section was selected as a basis for deriving ID numbers

Table 3. Type localities of bentonites

\begin{tabular}{|c|c|c|c|c|c|}
\hline $\begin{array}{c}\text { Viki } \\
\text { depth } \\
\text { ID }\end{array}$ & $\begin{array}{c}\text { ID } \\
\text { (Kiipli } \\
\text { et al. } \\
\text { 2001) }\end{array}$ & $\begin{array}{l}\text { Bentonite } \\
\text { name }\end{array}$ & Type locality & $\begin{array}{c}\text { Thick- } \\
\text { ness, } \\
\text { cm }\end{array}$ & Reference \\
\hline 127 & 29 & Ireviken & Ireviken section, Gotland, Sweden & 10 & Batchelor \& Jeppsson (1994) \\
\hline 150 & 28 & Lusklint & Lusklint section, Gotland, Sweden & 5 & Batchelor \& Jeppsson (1994) \\
\hline 210 & 27 & Ohesaare & Ohesaare drill-core, depth $345.8 \mathrm{~m}$ & 2 & Kiipli \& Kallaste (2006) \\
\hline 311 & & Aizpute & Aizpute drill-core, depth $931.8 \mathrm{~m}$ & 1 & Kiipli \& Kallaste (2006) \\
\hline 457 & 26 & Kirikuküla & Kirikuküla drill-core, depth $12.59 \mathrm{~m}$ & & \\
\hline 475 & 23 & Viki & Viki drill-core, depth $147.5 \mathrm{~m}$ & 5 & \\
\hline 480 & 21 & Kaugatuma & Kaugatuma drill-core, depth $261.1 \mathrm{~m}$ & 0.5 & \\
\hline 488 & 22 & Kuressaare & Kuressaare drill-core, depth $184.8 \mathrm{~m}$ & 0.5 & \\
\hline 494 & 19 & Ruhnu & Ruhnu drill-core, depth $473.7 \mathrm{~m}$ & 5 & \\
\hline 518 & 18 & Viirelaid & Viirelaid drill-core, depth $67.75 \mathrm{~m}$ & 1 & \\
\hline 520 & 17 & Lõetsa & Lõetsa drill-core, depth $47.2 \mathrm{~m}$ & 3 & \\
\hline 696 & 13 & Nässumaa & Nässumaa drill-core, depth $219.4 \mathrm{~m}$ & & \\
\hline 719 & 12 & Virtsu & Virtsu drill-core, depth $80.2 \mathrm{~m}$ & 1 & \\
\hline 731 & 11 & Nurme & Nurme drill-core, depth $17.9 \mathrm{~m}$ & 6 & \\
\hline 744 & 10 & Tehumardi & Tehumardi drill-core, depth $185.1 \mathrm{~m}$ & 1.2 & \\
\hline 755 & 9 & Paatsalu & Paatsalu drill-core, depth $81.5 \mathrm{~m}$ & 4 & \\
\hline 772 & 7 & Pahapilli & Pahapilli drill-core, depth $68.5 \mathrm{~m}$ & 5 & \\
\hline 795 & & Mustjala & Mustjala drill-core, depth $117.8 \mathrm{~m}$ & & \\
\hline 823 & 3 & Valgu & Valgu trench, Rapla district & 3 & \\
\hline 851 & 0 & Osmundsberg & Osmundsberget, Central Sweden & 115 & Bergström et al. (1998) \\
\hline
\end{tabular}


because of the great thickness of the Telychian, large number of bentonites, and a well-established conodont biostratigraphy (Jeppsson \& Männik 1993; Kiipli et al. 2001).

Names were assigned to 20 widespread bentonites recognized in more than five sections in Estonia (Table 3). Most of those were named after Estonian drill-cores where they were found. The Valgu Bentonite was named after the Valgu outcrop (Klaamann 1990) in southern Rapla District. The names of Osmundsberg, Lusklint, and Ireviken were applied on the basis of correlation with the described bentonites in the literature (Batchelor \& Jeppsson 1994; Bergström et al. 1998). The most frequent (found in 10-15 sections) bentonites in Estonia are as follows: Osmundsberg (851), Tehumardi (744), Nurme (731), Virtsu (719), Nässumaa (696), Lõetsa (520), Viirelaid (518), Ruhnu (494), Viki (475), and Kirikuküla (457). Correlation of these and other named bentonites forms a well-proved framework, where the stratigraphic position of rarely occurring bentonites can be established.

\section{DISCUSSIONS ON SEDIMENTOLOGY IN THE TELYCHIAN}

Bentonites were formed from very fine-grained volcanic dust and are therefore rarely preserved in shallow-water sediments from where wave activity transports fine ash material to the deeper and quieter sedimentary environments. The Telychian sediments in Estonia are represented by relatively deep-water marlstones and limestones, containing therefore a large number of bentonites. Despite a presumed quiet sedimentary environment, the record of bentonites in these sediments is still uneven. As a maximum, only 22 out of the total of 43 bentonites were found in one core (Ohesaare). Although the completeness of an established bentonite record depends partly on the quality of drilling and the experience of the sample-collecting researcher, the studied material revealed some regularities in the natural distribution of bentonites (Kiipli \& Kallaste 2002 and the present study):

1. The Ireviken and Lusklint bentonites occur only in the sections of southwestern Saaremaa. They are lacking in eastern Saaremaa and mainland Estonia. Often even the Ohesaare and Aizpute bentonites are absent there. This gap in the bentonite record was probably caused by a break in sedimentation near the Llandovery-Wenlock boundary, which was also proposed on the basis of biostratigraphical evidence (Nestor \& Nestor 2002, 2003). Now this is also confirmed by the distribution of bentonites.

2. In many drill-cores in the eastern part of the study area several bentonites are absent in the lower part of the Velise Formation and the Velise-Rumba transition interval. The most extensive gap in the bentonite records was established in the Ruhnu section, where even the bentonites of the Rumba Formation are entirely absent. In mainland Estonia, the Paatsalu section is the 
only exception with its almost full record of bentonites in the lower part of the Velise Formation. The best records of bentonites in this interval were established in the southwestern part of Saaremaa Island (Tehumardi, Viki, and Ohesaare sections). This gap in the record of bentonites was possibly caused by a major hiatus in sedimentation near the Rumba-Velise boundary.

3. Correlation of bentonites from the Nurme section is provisional as all bentonites there are very rich in authigenic feldspar, which complicates seriously the analysis of sanidine. The Nurme and Tehumardi bentonites were identified on the basis of sanidine composition, but other bentonites were correlated only graphically.

4. Correlation of bentonites 518, 520, and 521 (embraced by the frame in Table 2) is provisional as these bentonites reveal similar wide sanidine reflections and occur closely in a section. The occurrence of at least three bentonites with similar properties at this level is proved by the Kuressaare section, where all three bentonites were found.

5. In some cases an extremely low rate of sedimentation caused the deposits of two succeeding eruptions to merge. As a result, the sanidine originating from those different eruptions occurs within a single volcanic ash bed. The examples are $731+744$ (Nurme and Tehumardi bentonites) in the Ruhnu section and $823(\mathrm{Valgu})+818$ bentonites in the Ohesaare section.

6. The occurrence of a mixed $(823+818)$ bentonite in the Ohesaare section at $370.77 \mathrm{~m}$, which in other sections is found in the Rumba-Velise transition interval, indicates the presence of a condensed marlstone section in Ohesaare (370.9-372.6 m) corresponding to the Rumba Formation in shallow-water sections.

7. The mapped thickness of the volcanic ash layer can provide useful information on the direction of wind at the time of eruption and location of the source volcano. Up to now only the Kinnekulle eruption layer (Caradoc) is well mapped over a large area in Baltoscandia (Vingisaar 1972; Bergström et al. 1995). A number of the Osmundsberg Bentonite outcrop sites were described by Bergström et al. (1998). The thickness map of the Osmundsberg Bentonite in Estonia, presented by Kiipli et al. (2006), indicates ash transport from the northwest. The thickness of three other Telychian bentonites in Estonia shows different distribution patterns (Fig. 2). The Ruhnu Bentonite is characterized by even distribution of thickness $(3-5 \mathrm{~cm})$. Possibly the source volcano was located so far that no changes could be observed within the small studied area measuring $150 \mathrm{~km} \times 200 \mathrm{~km}$. The thickness of the Nässumaa and Nurme bentonites decreases rapidly to the southeast, probably perpendicular to the ash cloud axis. If this interpretation is correct, the Nässumaa ash was transported from the southwest and the Nurme ash from the west.

8. Restricted distribution of several bentonites, including all new discoveries, can be explained by patchy sedimentation accompanied by areas of 0 -sedimentation, small thickness of many bentonites complicating their identification, and loss of soft bentonite interbeds during drilling. 

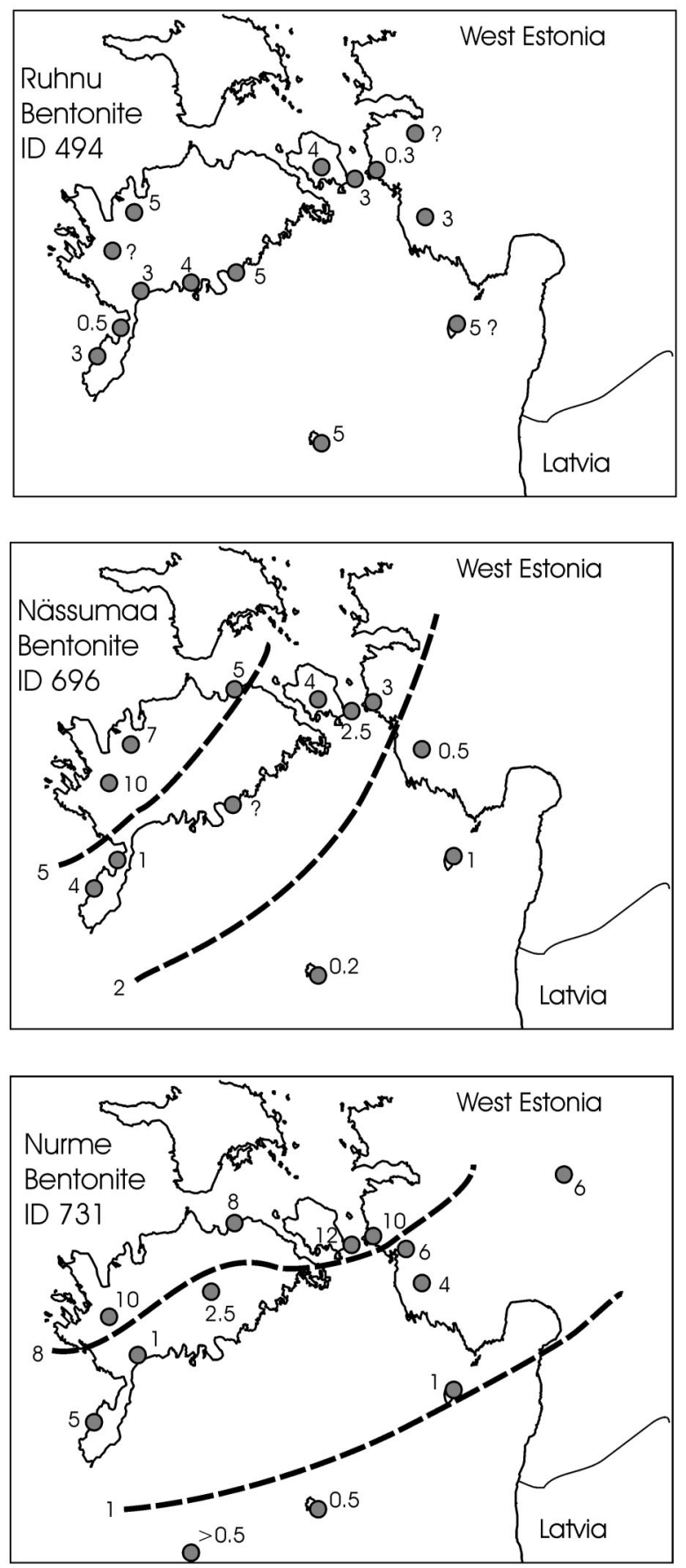

Fig. 2. Thickness $(\mathrm{cm})$ distribution patterns of the Ruhnu, Nässumaa, and Nurme bentonites in Estonia. 


\section{CONCLUSIONS}

The study of bentonites in new Telychian sections revealed a more complete volcanogenic record in Estonia including bentonites from 43 different volcanic eruptions. The assigned ID numbers and stratigraphic names make it easier to handle the information available on bentonites. New correlations enable us to trace gaps in the sedimentary record. Large hiatuses were confirmed at the transition of the Rumba and Velise formations and the Llandovery-Wenlock boundary. On the basis of the identification of bentonites, we assume that the deep-sea marlstone in the Ohesaare section correlates with the shallow-water Rumba Formation. Thickness distribution patterns of bentonites indicate volcanic ash transport from different directions and, correspondingly, from different sources.

\section{ACKNOWLEDGEMENTS}

This study is a contribution to IGCP project 503 and was supported by the Estonian Science Foundation (grants 5921, 6749, and target funding project 0332652s04). We are grateful to the referees D. Kaljo and R. A. Batchelor for useful comments and suggestions.

\section{REFERENCES}

Batchelor, R. A. \& Jeppsson, L. 1994. Late Llandovery bentonites from Gotland, Sweden, as chemostratigraphic markers. J. Geol. Soc. London, 151, 741-746.

Bergström, S. M., Huff, W. D., Kolata, D. R. \& Bauert, H. 1995. Nomenclature, stratigraphy, chemical fingerprinting and areal distribution of some Middle Ordovician K-bentonites in Baltoscandia. GFF, 117, 1-13.

Bergström, S. M., Huff, W. D. \& Kolata, D. R. 1998. The Lower Silurian Osmundsberg K-bentonite. Part I: stratigraphic position, distribution, and palaeogeographic significance. Geol. Mag., 135, 1-13.

Einasto, R., Nestor, H., Kala, E. \& Kajak, K. 1972. Correlation of the Upper Llandoverian sections in West Estonia. Eesti NSV Tead. Akad. Toim. Keemia Geol., 21, 333-343 (in Russian).

Hints, O., Killing, M., Männik, P. \& Nestor, V. 2006. Frequency patterns of chitinozoans, scolecodonts, and conodonts in the upper Llandovery and lower Wenlock of the Paatsalu core, western Estonia. Proc. Estonian Acad. Sci. Geol., 55, 128-155.

Jürgenson, E. 1964. Silurian metabentonites of Estonian SSR. In Litologiya Paleozojskikh otlozhenij Estonii, pp. 87-100. Institute of Geology, Tallinn (in Russian).

Jeppsson, L. \& Männik, P. 1993. High resolution correlations between Gotland and Estonia near the base of the Wenlock. Terra Nova, 5, 348-358.

Kiipli, E., Kiipli, T. \& Kallaste, T. 2006. Identification of the O-bentonite in the deep shelf sections with implication on stratigraphy and lithofacies, East Baltic Silurian. GFF (submitted).

Kiipli, T. \& Kallaste, T. 2002. Correlation of Telychian sections from shallow to deep sea facies in Estonia and Latvia based on the sanidine composition of bentonites. Proc. Estonian Acad. Sci. Geol., 51, 143-156.

Kiipli, T. \& Kallaste, T. 2003. Altered volcanic ash beds. In Ruhnu (500) Drill Core (Põldvere, A., ed.), Estonian Geol. Sections, 5, 31-33. 
Kiipli, T. \& Kallaste, T. 2006. Wenlock and uppermost Llandovery bentonites as stratigraphic markers in Estonia, Latvia and Sweden. GFF, 128, 139-146.

Kiipli, T., Männik, P., Batchelor, R. A., Kiipli, E., Kallaste, T. \& Perens, H. 2001. Correlation of Telychian (Silurian) altered volcanic ash beds in Estonia, Sweden and Norway. Norwegian J. Geol., 81, 179-194.

Klaamann, E. 1990. Locality 8:3 Valgu outcrop. In Field Meeting Estonia 1990 (Kaljo, D. \& Nestor, H., eds), pp. 181-182. Estonian Academy of Sciences, Tallinn.

Nestor, H. \& Nestor, V. 2002. Upper Llandovery to Middle Wenlock (Silurian) lithostratigraphy and chitinozoan biostratigraphy in southwestern Estonia and northernmost Latvia. Proc. Estonian Acad. Sci. Geol., 51, 67-87.

Nestor, H. \& Nestor, V. 2003. Adavere lademe vanusest ja piiridest. In Eesti Geoloogide neljas ülemaailmne kokkutulek. Eesti geoloogia uue sajandi künnisel. Konverentsi materjalid ja ekskursioonijuht (Plado, J. \& Puura, I., eds), pp. 53-55. EGS, TÜ Geoloogia Instituut.

Nestor, V. 1994. Early Silurian chitinozoans of Estonia and North Latvia. Academia, 4.

Orville, P. M. 1967. Unit-cell parameters of the microcline-low albite and the sanidine-high albite solid solution series. Amer. Mineral., 52, 55-86.

Vingisaar, P. 1972. On the distribution of the main metabentonite stratum (d, XXII) in the Middle Ordovician of Baltoscandia. Eesti NSV Tead. Akad. Toim. Keemia Geol., 21, 62-70 (in Russian).

\section{Telychi (Silur) bentoniitide uued korrelatsioonid Eestis}

\section{Toivo Kallaste ja Tarmo Kiipli}

Sanidiini koostise alusel on korreleeritud seitsekümmend seitse bentoniiti kuuest puursüdamikust. Kokku on kindlaks tehtud bentoniite neljakümne kolmest vulkaanipurskest. Avastatud on kuus uut bentoniiti. Bentoniitidele on omistatud stratigraafilised nimed ja ID-koodid. On diskuteeritud vulkaanilise tuha levikusuundade ja ümbriskivimi sedimentoloogia üle. 